\title{
Rekomendasi Hasil Metode Weighted Product terhadap Pemilihan Tempat Kuliner di Sekitar Universitas Bhayangkara Bekasi
}

\author{
Recommendation Results of Weighted Product Method Towards the Selection of \\ Culinary Place Around Universitas Bhayangkara in Bekasi
}

\author{
Fata Nidaul Khasanah ${ }^{1}$, Herlawati $^{2}$, Prima Dina Atika ${ }^{3}$, Rafika Sari $^{4}$, Sugeng Murdowo ${ }^{5}$, \\ Endang Retnoningsih ${ }^{6}$ \\ 1,2,3,4 Jurusan Informatika, Universitas Bhayangkara Jakarta Raya \\ ${ }^{5}$ Jurusan Komputerisasi Akuntansi, AMIK Jakarta Teknologi Cipta Semarang \\ ${ }^{6}$ Jurusan Teknik Komputer, Universitas Islam 45 Bekasi \\ E-mail: '1fatanidaul@gmail.com, ${ }^{2}$ herlawati@ubharajaya.ac.id, \\ ${ }^{3}$ prima.dina@dsn.ubharajaya.ac.id, ${ }^{4}$ rafika.sari@dsn.ubharajaya.ac.id, \\ ${ }^{5}$ sugengmurdowo0298@gmail.com, ${ }^{6}$ endang.retnoningsih44@gmail.com
}

\begin{abstract}
Abstrak
Bisnis kuliner semakin dinamis disebabkan perubahan selera konsumen, orang-orang cenderung mengunjungi tempat kuliner pilihan dengan pertimbangan kriteria dan mengikuti perkembangan trend. Pengumpulan data menggunakan google trends untuk mengetahui trend masyarakat terhadap tempat kuliner di Bekasi dan google maps khusususnya untuk memperoleh tempat kuliner disekitar Universitas Bhayangkara Jakarta Raya di Bekasi. Metode Weighted Product (WP) mampu memberikan hasil keputusan berupa rekomendasi tempat kuliner di kota Bekasi berdasarkan kriteria dan memberikan hasil berdasarkan nilai alternatif tertinggi. Kriteria penelitian dalam memilih tempat kuliner berdasarkan harga, jumlah varian menu, rating dan jarak. Alternatif yang diberikan sejumlah sepuluh tempat yang direkomendasikan. Berdasarkan perhitungan diperoleh hasil alternatif delapan merupakan rekomendasi tempat kuliner yang dipilih karena memiliki hasil nilai preferensi atau vektor V tertinggi sebesar 0,126. Dengan tingkat akurasi metode Weighted Product sebesar 70\% termasuk dalam kategori cukup baik.
\end{abstract}

Kata kunci: Bekasi, Kuliner, Metode Weighted Product, Rekomendasi

\begin{abstract}
The culinary business is increasingly dynamic due to changes in consumer tastes, people tend to visit selected culinary places by considering criteria and following trends. Data collection uses google trends to find out community trends towards culinary places in Bekasi and google maps in particular to get culinary places around Bhayangkara University, Greater Jakarta in Bekasi. The Weighted Product (WP) method is able to provide decision results in the form of recommendations for culinary places in the city of Bekasi based on criteria and provide results based on the highest alternative value. Research criteria in choosing a culinary place based on price, number of menu variants, rating and distance. The alternatives given are ten recommended places. Based on the calculation, the eight alternative results are recommendations for the selected culinary places because they have the highest preference value or Vvector of 0.126. With an accuracy rate of $70 \%$ of the Weighted Product method, it is included in the fairly good category.
\end{abstract}

Keywords: Bekasi, Culinary, Weighted Product Method, Recommendations 


\section{PENDAHULUAN}

Bisnis kuliner selalu potensial untuk dikembangkan, karena menyediakan salah satu kebutuhan pokok manusia. Faktor yang perlu diperhatikan agar bisa sukses dalam bisnis kuliner adalah cara memilih lokasi yang sesuai memang penting seperti lokasi strategis mendekatkan diri dengan target pasar akan berpengaruh baik terhadap usaha, selain itu juga perlu dipastikan akses jalan harus mudah [1]. Bisnis kuliner termasuk bisnis lokal yang target marketnya penduduk sekitar dengan karakteristik demografi yang beragam, bisnis kuliner juga semakin dinamis hal ini disebabkan perubahan selera konsumen dan lingkungan [2], selain itu perkembangan teknologi dan trend seperti banyaknya pencarian kata kunci dari data google trend yang berkaitan dengan kuliner di lokasi tertentu.

Orang-orang cenderung mengunjungi dengan pertimbangan hal budget, jenis makanan, fasilitas, lokasi dan juga jam buka, beberapa kriteria yang digunakan dapat saling bertentangan dengan kriteria lainnya seperti harga yang sesuai budget tetapi jenis makanan tidak sesuai keinginan, atau fasilitas yang sesuai harapan tetapi lokasinya jauh, hal seperti ini sehingga tidak dapat diselesaikan menggunakan rumus matematika linier umum sehingga permasalahan ini termasuk permasalahan yang bersifat tidak terstruktur [3], [4].

Pemanfaatan teknologi untuk mengembangkan bisnis merupakan proses pengubahan data menjadi informasi, informasi-informasi tersebut diambil polanya menjadi suatu pengetahuan bagi pengguna untuk pengambilan keputusan [5]. Pengolahan informasi yang diperlukan untuk pengambilan keputusan yang dibuat akan mempunyai landasan yang sesuai kenyataan dengan menggunakan sistem penunjang keputusan dalam menggunakan data dan model untuk memecahkan permasalahan yang bersifat tidak terstruktur, dengan kemampuan adaptif terhadap perubahan kondisi [6]. Pemanfaatan tekologi informasi, khususnya dalam bidang penyediaan jasa, sistem dengan model pengambilan keputusan merupakan keunggulan kompetitif bertujuan meningkatkan benefit yang dinamis dengan mengandalkan kecepatan dan keakuratan memproses dan perhitungan data menjadi informasi [7], [8]. Memilih berbagai alternatif sebagai solusi merupakan hasil pengambilan keputusan untuk memecahkan permasalahan [9].

Penelitian yang terkait dengan pemilihan tempat kuliner yang telah dilakukan beberapa peneliti sebelumnya. Diantaranya [10] membahas tentang metode Weighted Product (WP) dalam memberikan hasil rekomendasi yang dapat membantu wisatawan terkait informasi pemilihan tujuan wisata dan kuliner di Malang menggunakan kriteria harga, pelayanan, suasana dan kualitas. Metode $W P$ juga diimplementasikan dalam penelitian pencarian restoran di Lampung berbasis website, dari penelitian ini kriteria yang digunakan harga, rating dan kapasitas [11].

Pembahasan dari penelitian ini kriteria yang digunakan dalam menentukan rekomendasi tempat kuliner adalah harga, jumlah varian menu, rating dan jarak, menggunakan metode WP sehingga mampu memberikan hasil keputusan berupa rekomendasi tempat kuliner di kota Bekasi berdasarkan kriteria penilaian yang ditentukan dan alternatif tempat kuliner yang diberikan. Hasil rekomendasi yang diperoleh dilanjutkan dengan melakukan uji akurasi.

\section{METODE PENELITIAN}

Kegiatan pengumpulan data merupakan bagian penting dalam proses pengambilan keputusan [12], oleh karenanya dalam penyelesaian masalah diperlukan metode agar penyelesaian yang dilakukan tidak menimbulkan masalah baru. Teknik pengambilan keputusan dalam sistem pendukung keputusan (SPK) yaitu intelegence, design, choice dan implementation [13], [14].

Intelegence merupakan penelusuran problematika dalam sistem berdasarkan data masukan yang diproses untuk mengidentifikasi permasalahan. Design melakukan analisis alternatif dan menguji kelayakan solusi yang diperoleh. Choice untuk membuat pilihan dari alternatif yang tersedia untuk mendukung keputusan yang diambil. Selanjutnya mengimplementasikan ke proses pengambilan keputusan sesuai alternatif dan tujuan yang diharapkan. 


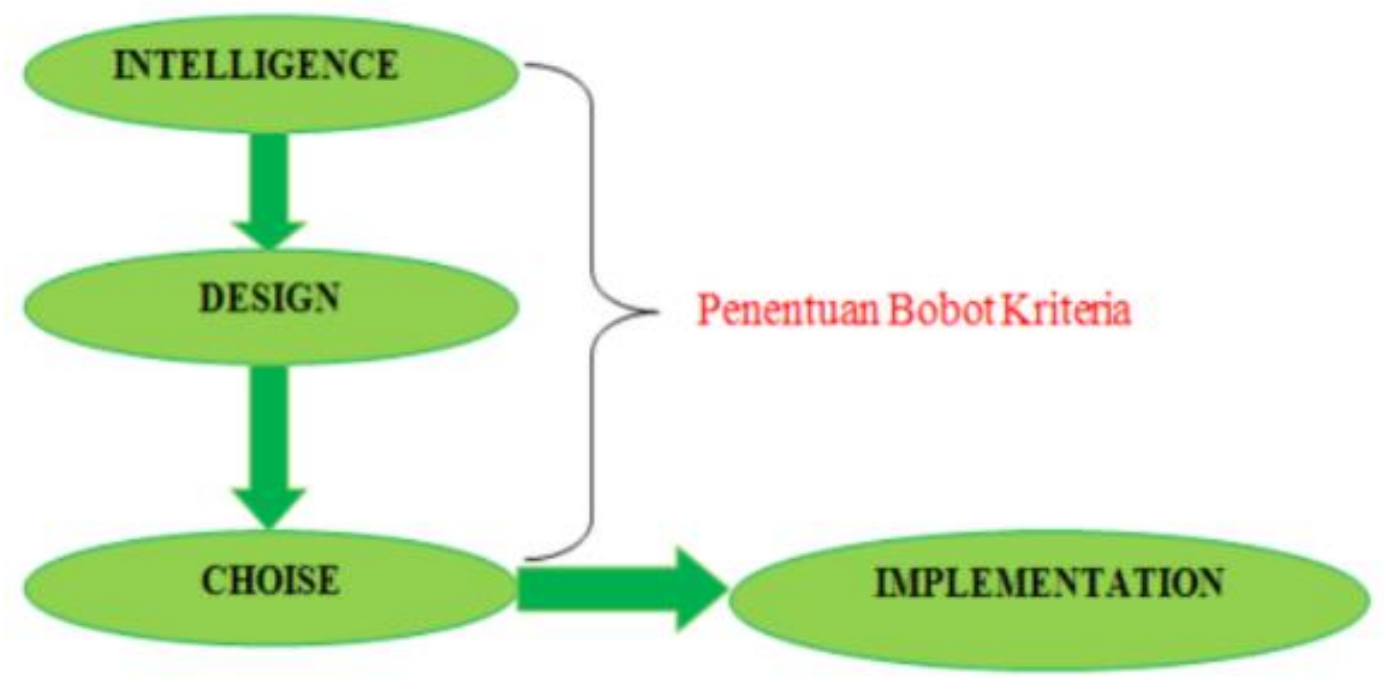

Gambar 1 Fase Proses Pengambilan Keputusan dalam SPK

\subsection{Data}

Masyarakat saat ini menjadikan tren berburu kuliner sebagai gaya hidup, data trend masyarakat ini diperoleh dari google trends (https://trends.google.com) berdasarkan pencarian kata kunci tempat kuliner, harga, dan juga jarak yang menjadi faktor pertimbangan dalam menentukan tempat kuliner [15].

$\leftarrow \rightarrow$ C trends.google.co.id/trends/explore?cat=71\&geo=ID\&q=kuliner\%20bekasi,price,distance

\section{$\equiv$ Google Trends $\quad$ Compare}

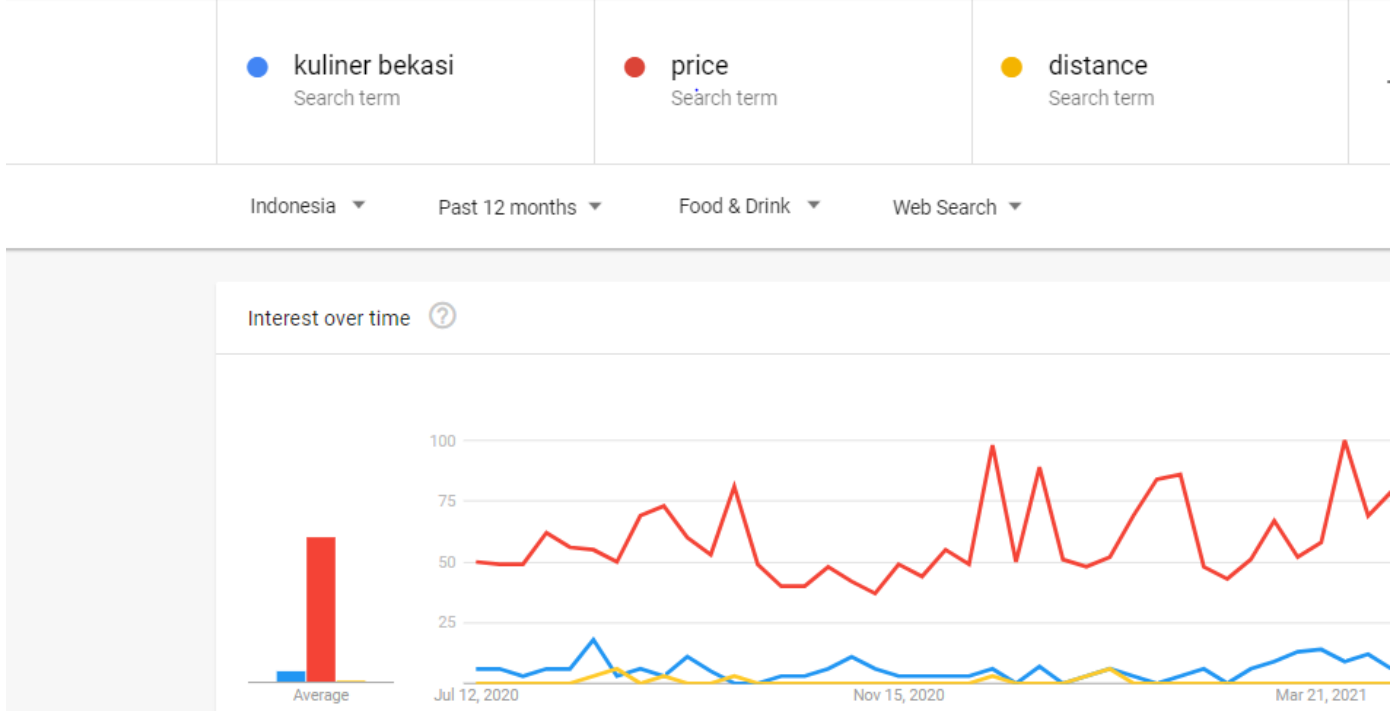

Gambar 2 Trend Pencarian Tempat Kuliner di Bekasi

Berdasarkan data yang tercatat pada Badan Pusat Statistik Kabupaten Bekasi jumlah restoran di sekitar kabupaten Bekasi terdapat 28 tempat kuliner dan di kota Bekasi sejumlah 104 tempat kuliner di Bekasi [16], menjadi salah satu faktor dilakukannya penelitian untuk memberikan rekomendasi kepada masyarakat dalam menentukan pilihan tempat kuliner. 


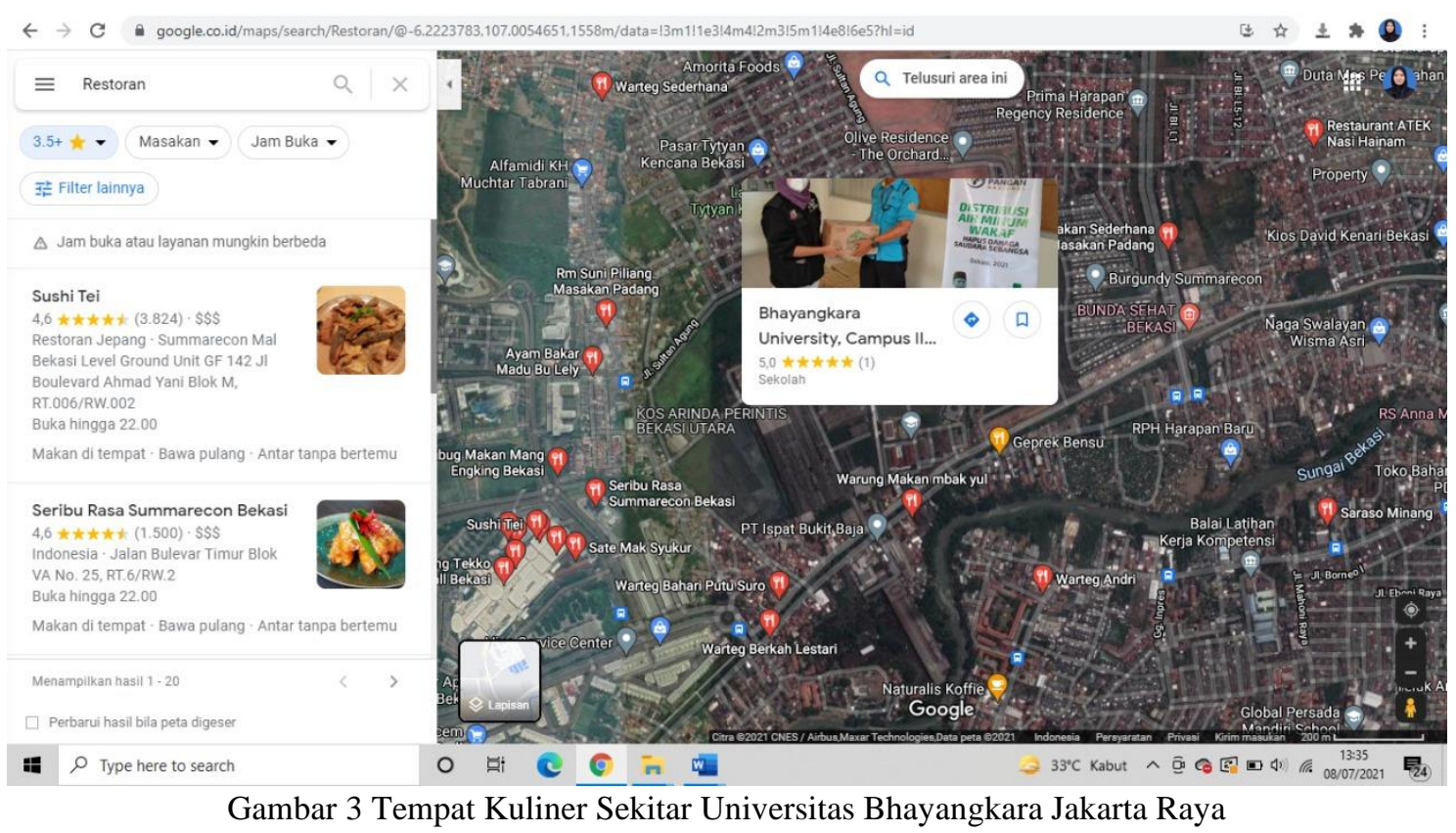

Berdasarkan data tersebut nantinya akan dilakukan pemilihan beberapa daftar tempat kuliner yang dijadikan sebagai alternatif untuk dilanjutkan dengan proses perhitungan dengan menggunakan metode Weighted Product sehingga diperoleh hasil rekomendasi tempat kuliner.

\subsection{Metode Weighted Product (WP)}

Metode Weighted Product (WP) banyak digunakan dalam menyelesaikan permasalahan yang bersifat Multiple Attribute Decision Making, dengan metode pembobotan WP perhitungam matematis menghubungkan rating atribut dengan bobot atribut yang bersangkutan menjadi normalisasi [17], [18]. Proses perangkingan dari menyeleksi alternatif terbaik dan perhitungan yang lebih singkat menjadi kelebihan metode WP [10], [19]. Berikut algoritma penyelesaian Weighted Product [20]: 1) menentukan kriteria penilaian yang dijadikan sebagai patokan dalam penyelesaian masalah; 2) menetukan alternatif; 3) menentukan bobot preferensi setiap kriteria; 4) melakukan perbaikan bobot atau normalisasi bobot; 5) menormalisasi nilai setiap alternatif atau menentukan nilai vektor $S$; 6) menentukan nilai preferensi atau nilai vektor $\mathrm{V}$; 7) memperoleh hasil berdasarkan nilai alternatif tertinggi.

Melakukan perbaikan bobot atau normalisasi bobot pada tahap keempat ditentukan dengan menggunakan rumus (1).

$$
w_{j}=\frac{w}{\Sigma_{w}} \text { dimana nilai } \sum w_{j}=1
$$

Menormalisasi matriks atau menentukan nilai vektor S pada tahap kelima menggunakan rumus (2).

$$
S_{i}=\Pi_{j=1}^{n} x_{i_{i}}^{w_{j}} \text { dimana nilai } i=1,2, \ldots, n
$$

Dalam menentukan nilai vektor S perlu memperhatikan kategori dari kriteria yang digunakan merupakan kategori keuntungan (benefit) atau biaya (cost). $\mathrm{w}_{\mathrm{j}}$ adalah pangkat bernilai positif untuk jenis kriteria keuntungan dan bernilai negatif untuk jenis kriteria biaya. 
Menentukan nilai preferensi atau vektor $\mathrm{V}$ diperoleh menggunakan rumus (3), yaitu dengan membagi hasil dari vektor $S$ untuk setiap alternatif dengan jumlah keseluruhan vektor $S$.

$$
V_{i}=\frac{s_{i}}{\Pi_{j=1\left(x_{j}^{*}\right)}^{n} w_{j}}
$$

\subsection{Uji Akurasi}

Penelitian ini melakukan pengujian terhadap hasil penerapan metode Weighted Product dalam menentukan rekomendasi tempat kuliner dengan menggunakan uji akurasi. Uji akurasi memiliki tujuan untuk mengetahui tingkat performa dari suatu metode pendukung keputusan dalam memberikan hasil keputusan [21]. Berdasarkan uji akurasi nantinya diperoleh kriteria klasifikasi baik, cukup baik, kurang baik dan tidak baik. Adapun nilai prosentase dari setiap kriteria, yaitu klasifikasi baik dengan rentang nilai $76 \%$ - 100\%, klasifikasi cukup baik dengan rentang nilai 56\% - 75\%, klasifikasi kurang baik dengan rentang nilai 40\% - 55\% dan klasifikasi tidak baik dengan nilai kurang dari $40 \%$ [22]. Uji akurasi dapat ditentukan dengan menggunakan persamaan rumus (4).

$$
\text { Akurasi }(\%)=\frac{\sum \text { data uji benar }}{\sum \text { data uji total }} \times 100 \%(4)
$$

\section{HASIL DAN PEMBAHASAN}

Pembahasan pada bagian ini mengenai hasil penerapan metode $W P$ dalam memberikan hasil rekomendasi penentuan tempat kuliner dan hasil uji akurasi dari metode tersebut.

\subsection{Metode Weighted Product (WP)}

Kriteria penilaian yang digunakan pada penelitian ini terdiri dari harga, jumlah varian menu, rating dan jarak. Pada tabel 1 menunjukkan data jenis kategori kriteria penilaian yang digunakan.

Tabel 1 Data Jenis dan Kategori Kriteria

\begin{tabular}{|l|l|l|}
\hline Kode & Kriteria & Kategori Kriteria \\
\hline K-1 & Harga & Biaya \\
\hline K-2 & Jumlah Varian Menu & Keuntungan \\
\hline K-3 & Rating & Keuntungan \\
\hline K-4 & Jarak & Keuntungan \\
\hline
\end{tabular}

Tabel 2 menunjukkan data nilai dari setiap alternatif terhadap masing-masing kriteria penilaian yang digunakan.

Tabel 2 Nilai Alternatif untuk Tiap Kriteria

\begin{tabular}{|c|c|c|c|c|}
\hline Alternatif & K-1 & K-2 & K-3 & K-4 \\
\hline A-1 & 3 & 5 & 5 & 4 \\
\hline A-2 & 4 & 3 & 4 & 3 \\
\hline A-3 & 4 & 5 & 4 & 3 \\
\hline A-4 & 1 & 3 & 5 & 1 \\
\hline A-5 & 2 & 5 & 5 & 2 \\
\hline A-6 & 3 & 2 & 5 & 4 \\
\hline A-7 & 2 & 2 & 5 & 1 \\
\hline A-8 & 1 & 5 & 5 & 1 \\
\hline A-9 & 3 & 2 & 5 & 2 \\
\hline A-10 & 2 & 2 & 5 & 2 \\
\hline
\end{tabular}


Penentuan bobot preferensi pada tiap kriteria, yaitu K-1=0,4; K-2=0,1; K-3=0,3; K-4=0,2. Setelah menentukan nilai bobot dari setiap kriteria diberikan maka tahap selanjutnya melakukan normalisasi bobot dengan menggunakan rumus persamaan (1), dimana nilai bobot dari tiap kriteria dibagi dengan jumlah seluruh bobot kriteria penilaian. Jumlah dari normalisasi bobot nantinya sama dengan satu atau $\sum w_{j}=1$. Berikut perhitungan dalam menentukan normalisasi bobot.

$$
\begin{aligned}
& w 1=\frac{0,4}{0,4+0,1+0,3+0,2}=0,4 \\
& w 2=\frac{0,1}{0,4+0,1+0,3+0,2}=0,1 \\
& w 3=\frac{0,3}{0,4+0,1+0,3+0,2}=0,3 \\
& w 4=\frac{0,2}{0,4+0,1+0,3+0,2}=0,2
\end{aligned}
$$

Setelah diperoleh hasil normalisasi bobot maka tahap selanjutnya menormalisasi matriks atau menentukan vektor $S$ dengan menggunakan rumus persamaan (2). Dalam melakukan normalisasi matriks perlu memperhatikan jenis kategori kriteria yang digunakan. Berikut adalah contoh hasil perhitungan dalam melakukan normalisasi matriks untuk alternatif pertama sampai dengan alternatif kedua. Tabel 3 menunjukkan hasil normalisasi matriks dari seluruh alternatif.

$$
\begin{aligned}
& S 1=\left(3^{-0,4}\right) \times\left(5^{0,1}\right) \times\left(5^{0,3}\right) \times\left(4^{0,2}\right)=1,619 \\
& S 2=\left(4^{-0,4}\right) \times\left(3^{0,1}\right) \times\left(4^{0,3}\right) \times\left(3^{0,2}\right)=1,210
\end{aligned}
$$

Tabel 3 Hasil Vektor S

\begin{tabular}{|c|c|}
\hline Alternatif & Vektor S \\
\hline A-1 & 1,619 \\
\hline A-2 & 1,210 \\
\hline A-3 & 1,274 \\
\hline A-4 & 1,809 \\
\hline A-5 & 1,657 \\
\hline A-6 & 1,477 \\
\hline A-7 & 1,316 \\
\hline A-8 & 1,904 \\
\hline A-9 & 1,286 \\
\hline A-10 & 1,512 \\
\hline
\end{tabular}

Berdasarkan hasil tabel 3 diperoleh jumlah dari nilai vektor S adalah 15,064. Selanjutnya menentukan perhitungan nilai preferensi atau vektor $\mathrm{V}$ menggunakan persamaan 3. Berikut adalah contoh perhitungan dalam menentukan nilai vektor $\mathrm{V}$ pada alternatif pertama dan alternatif kedua.

$$
\begin{aligned}
& V 1=\frac{1,619}{15,064}=0,107 \\
& V 2=\frac{1,210}{15,064}=0,080
\end{aligned}
$$


Tabel 4 menunjukkan hasil dari nilai preferensi dari setiap alternatif penilaian.

Tabel 4 Hasil Nilai Vektor V

\begin{tabular}{|c|c|}
\hline Alternatif & Vektor V \\
\hline A-1 & 0,107 \\
\hline A-2 & 0,080 \\
\hline A-3 & 0,085 \\
\hline A-4 & 0,120 \\
\hline A-5 & 0,110 \\
\hline A-6 & 0,098 \\
\hline A-7 & 0,087 \\
\hline A-8 & 0,126 \\
\hline A-9 & 0,085 \\
\hline A-10 & 0,100 \\
\hline
\end{tabular}

Gambar 4 menunjukkan grafik hasil nilai preferensi dari setiap alternatif berdasarkan perhitungan metode $W P$.

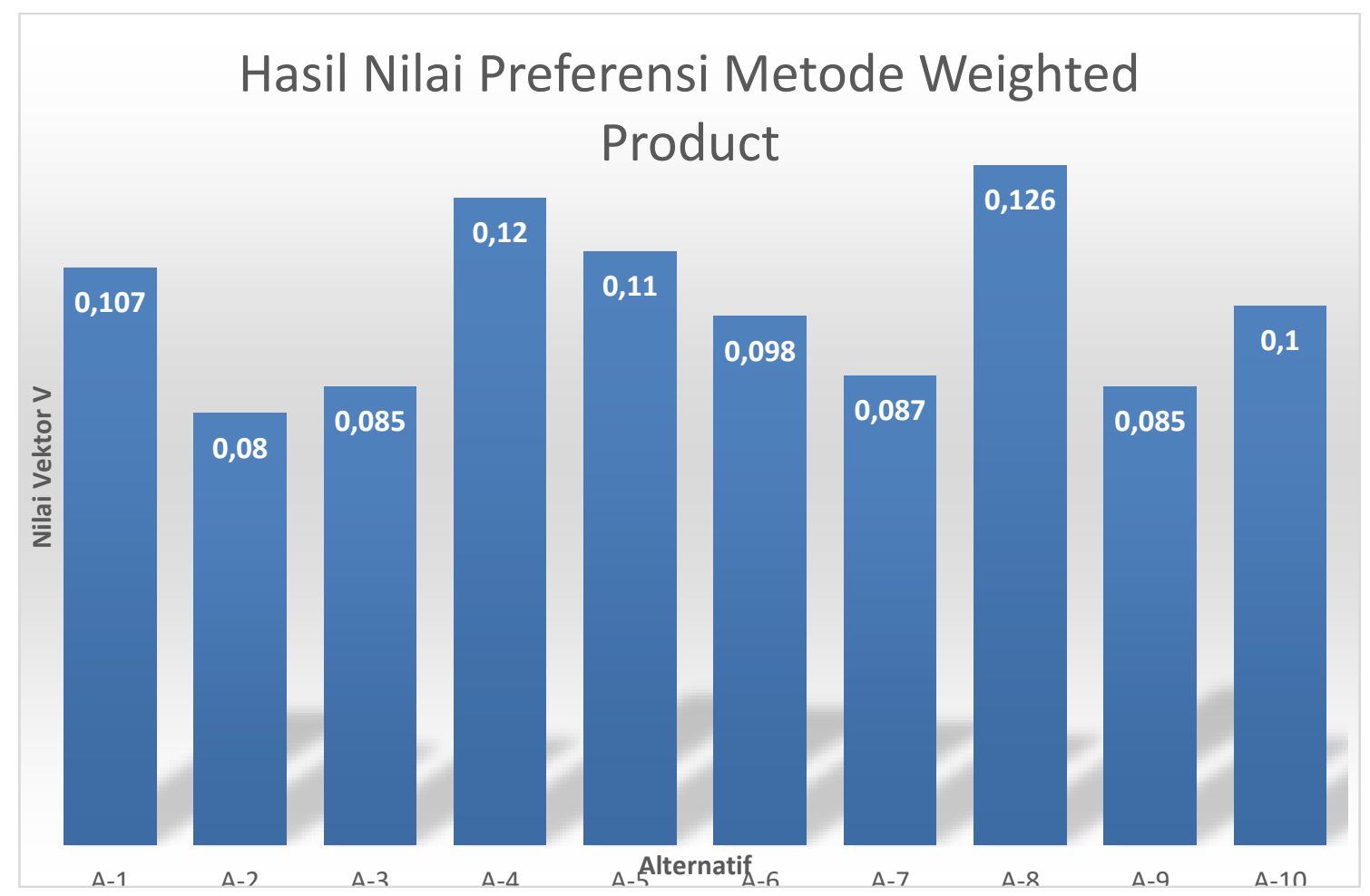

Gambar 4 Grafik Hasil Setiap Alternatif 


\subsection{Uji Akurasi}

Hasil dari proses perhitungan dengan metode Weighted Product diperoleh urutan perangkingan dimulai dari nilai preferensi tertinggi sampai dengan nilai preferensi terendah ditunjukkan pada tabel 5 .

Tabel 5 Hasil Perangkingan

\begin{tabular}{|c|c|}
\hline Alternatif & Hasil Perankingan \\
\hline A-8 & 0,126 \\
\hline A-4 & 0,120 \\
\hline A-5 & 0,110 \\
\hline A-1 & 0,107 \\
\hline A-10 & 0,100 \\
\hline A-6 & 0,098 \\
\hline A-7 & 0,087 \\
\hline A-9 & 0,085 \\
\hline A-3 & 0,085 \\
\hline A-2 & 0,080 \\
\hline
\end{tabular}

Berdasarkan hasil perangkingan yang telah diperoleh maka dilakukan pengujian akurasi terhadap penerapan metode weighted product dalam memberikan hasil rekomendasi tempat kuliner. Uji akurasi ini dilakukan dengan melakukan perbandingan antara urutan alternatif dari hasil perangkingan metode weighted product terhadap urutan alternatif dari data kuisioner yang diperoleh untuk dilakukan pencocokan sesuai atau tidak sesuai. Tabel 6 menunjukkan hasil perbandingan antara metode $W P$ terhadap hasil kuisioner dan diperolehlah keterangan mengenai sesuai atau tidak sesuai dari hasil yang diberikan.

Tabel 6 Hasil Pencocokan Terhadap Alternatif

\begin{tabular}{|c|c|c|}
\hline Hasil $W P$ & Hasil Kuisioner & Keterangan \\
\hline A-8 & A-8 & Sesuai \\
\hline A-4 & A-4 & Sesuai \\
\hline A-5 & A-5 & Sesuai \\
\hline A-1 & A-6 & Tidak Sesuai \\
\hline A-10 & A-10 & Sesuai \\
\hline A-6 & A-9 & Tidak Sesuai \\
\hline A-7 & A-7 & Sesuai \\
\hline A-9 & A-1 & Tidak Sesuai \\
\hline A-3 & A-3 & Sesuai \\
\hline A-2 & A-2 & Sesuai \\
\hline
\end{tabular}

Perhitungan uji akurasi diperoleh dengan menggunakan rumus persamaan (4), sehingga diperoleh hasil yang sesuai sebanyak 7 alternatif dan 3 alternatif yang tidak sesuai. Dengan demikian tingkat akurasi yang diperoleh dari metode WP sebesar $70 \%$ sehingga hasil tersebut masuk dalam kategori cukup baik.

\section{KESIMPULAN DAN SARAN}

Penentuan rekomendasi tempat kuliner dapat dilakukan menggunakan metode keputusan Weighted Product dengan menggunakan kriteria penilaian yang digunakan, yaitu harga, varian jumlah menu, rating dan jarak. Berdasarkan hasil penerapan metode WP diperoleh hasil alternatif delapan merupakan rekomendasi tempat kuliner yang dipilih karena memiliki hasil nilai preferensi atau vektor $\mathrm{V}$ tertinggi sebesar 0,126. Selanjutnya dari hasil pengujian terhadapan penerapan metode $W P$ diperoleh hasil prosentasi uji akurasi sebesar $70 \%$, dengan demikian metode WP dianggap cukup baik dalam menentukan rekomendasi tempat kuliner di Bekasi 
khususnya di beberapa tempat kuliner yang terdapat di sekitar Universitas Bhayangkara Jakarta Raya.

\section{UCAPAN TERIMA KASIH}

Terima kasih peneliti ucapkan kepada Universitas Bhayangkara Jakarta Raya yang telah membiayai penelitian ini dalam bentuk Hibah Penelitian Internal untuk Tahun Anggaran 2021. Terima kasih juga penulis ucapkan kepada Lembaga Penelitian, Pengabdian kepada Masyarakat dan Publikasi (LPPMP) Universitas Bhayangkara Jakarta Raya dan Fakultas Ilmu Komputer Universitas Bhayangkara Jakarta Raya yang telah memberikan fasilitas dalam pelaksanaan penelitian ini.

\section{DAFTAR PUSTAKA}

[1] J. Pratama, "8 Tips Memilih Lokasi Yang Sesuai Untuk Usaha Restoran," https://www.wisklik.com/, 2019. .

[2] F. Hardiansyah, M. Nuhung, and I. Rasulong, "Pengaruh Lokasi dan Harga Terhadap Keputusan Pembelian pada Restoran Singapore di Kota Makassar," J. Profitab., vol. 3, no. 1, pp. 90-107, 2019.

[3] S. Zulqifli and S. Sutikno, "Sistem Pendukung Keputusan Pemilihan Tempat Kuliner Berbasis Android Menggunakan Model Fuzzy Mamdani," JIPI (Jurnal Ilm. Penelit. dan Pembelajaran Inform., vol. 2, no. 2, pp. 43-54, 2017, doi: 10.29100/jipi.v2i2.344.

[4] H. Supriyono and C. P. Sari, "Developing Decision Support Systems using the Weighted Product Method for House Selection," AIP Conf. Proc., vol. 1977, no. June 2018, pp. 020049-1-7, 2018, doi: 10.1063/1.5042905.

[5] Kusrini, Konsep dan Aplikasi Sistem Pendukung Keputusan. Yogyakarta: Andi Offset, 2007.

[6] Marimin, Sistem Pendukung Pengambilan Keputusan dan Sistem Pakar. Bogor: IPB Press, 2019.

[7] A. Andoyo et al., Sistem Pendukung Kaputusan Implementasi \& Pengembangan. Indramayu: CV. Adanu Abimata, 2021.

[8] D. R. N. D. N. Utama, Sistem Penunjang Keputusan: Filosofi, Teori dan Implementasi, no. April. Yogyakarta: Garudhawaca, 2017.

[9] A. Herdiansah, N. Handayani, and A. Kurniawan, "Development of Decision Support Systems Selection of Employee Acceptance Using Weighted Product Method," J. Inf. Syst. Informatics, vol. 1, no. 2, pp. 87-97, 2019.

[10] M. H. Adiansyah, M. Ahsan, and A. E. Budianto, "Implementasi Metode Weighted Product sebagai Sistem Rekomendasi Wisata dan Kuliner Favorit di Malang," RAINSTEK J. Terap. Sains Teknol., vol. 2, no. 2, pp. 147-153, 2020, doi: 10.21067/jtst.v2i1.4243.

[11] I. Setyorini and V. Sofica, "Animasi Interaktif Kosakata Dalam Dua Bahasa ( ArabInggris ) Pada RA Kuwait Pusdiklat Dewan Da' wah Bekasi," Bina Insa. ICT J., vol. 2, no. 2, pp. 85-100, 2015.

[12] Diana, Metode \& Aplikasi Sistem Pendukung Keputusan. Yogyakarta: Deepublish, 2018.

[13] T. Limbong et al., Sistem Pendukung Keputusan Metode \& Implementasi. Medan: Yayasan Kita Menulis, 2020.

[14] D. Nofriansyah and S. Defit, Multi Criteria Decision Making (MCDM) pada Sistem Pendukung Keputusan. Yogyakarta: Deepublish, 2017.

[15] Google Trends, "Google Trends," https://trends.google.co.id. 2021.

[16] Badan Pusat Statistik, "Banyaknya Rumah Makan/Restoran Menurut Kabupaten/Kota di Provinsi Jawa Barat, 2015 - 2018," https://bekasikab.bps.go.id. 2021.

[17] O. Bozorg-Haddad, B. Zolghadr-Asli, and H. A. Loaiciga, A Handbook on Multi-Attribute Decision-Making Methods - Google Books. Hoboken: John Wiley and Sons Inc, 2021.

[18] S. S. Pandean and S. Hansun, "Aplikasi Web untuk Rekomendasi Restoran Menggunakan 
Weighted Product," J. Teknol. Inf. dan Ilmu Komput., vol. 5, no. 1, pp. 87-94, 2018, doi: 10.25126/jtiik.201851626.

[19] W. Nengsih, "Analisa Akurasi Permodelan Supervised Dan Unsupervised," Sebatik, vol. 23, no. 2, pp. 285-291, 2019.

[20] F. N. Khasanah, H. Herlawati, R. T. Handayanto, D. Thamrin, P. Prasojo, and Erik Saut H Hutahaean, "Decision Support System For Student Scholarship Recipients Using Simple Additive Weighting Method with Sensitivity Analysis," in 2020 Fifth International Conference on Informatics and Computing (ICIC), 2020, pp. 652-658, doi: 10.1109/ICIC50835.2020.

[21] F. N. Khasanah and S. Rofiah, "Sistem Seleksi Penerimaan Beasiswa Menggunakan Metode Pendukung Keputusan Simple Additive Weighting," in Seminar Nasional APTIKOM (SEMNASTIK) 2019, 2019, pp. 118-125.

[22] R. I. Borman, D. A. Megawaty, and A. Attohiroh, "Implementasi Metode TOPSIS Pada Sistem Pendukung Keputusan Pemilihan Biji Kopi Robusta Yang Bernilai Mutu Ekspor (Studi Kasus : PT. Indo Cafco Fajar Bulan Lampung)," Fountain Informatics J., vol. 5, no. 1, p. 14, 2020, doi: 10.21111/fij.v5i1.3828. 